症例

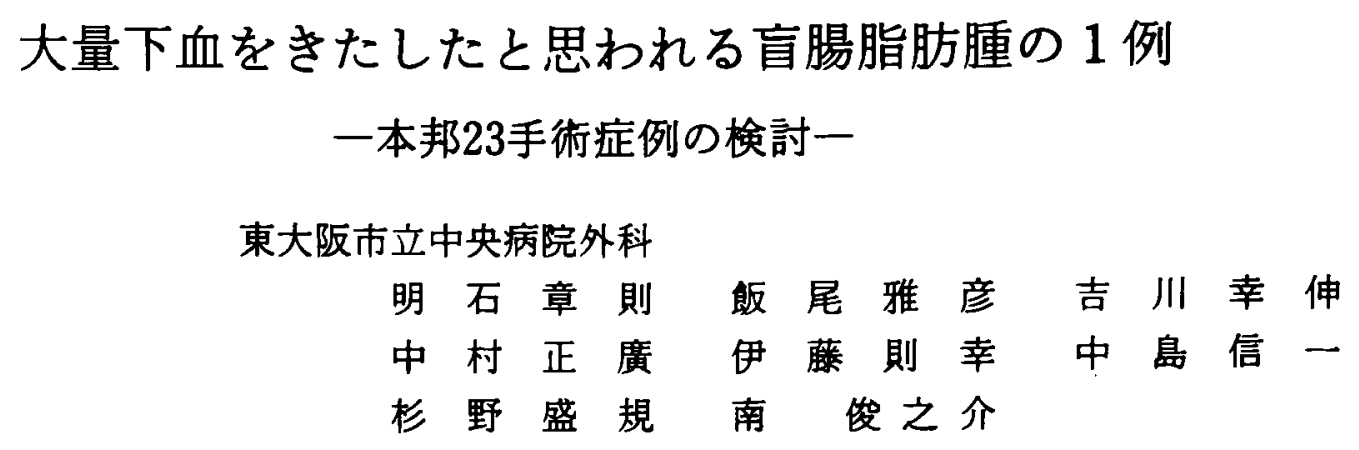

\title{
A CASE OF LIPOMA OF THE CECUM PROBABLY CAUSING MASSIVE RECTAL BLEEDING AND THE ANALYSIS OF 23 CASES REPORTED IN JAPAN
}

Akinori AKASHI, Masahiko IIO, Yukinobu YOSHIKAWA, Masahiro NAKAMURA, Noriyuki ITO, Shinichi NAKASHIMA, Seiki SUGINO and Shunnosuke MINAMI Department of Surgery, Higashiosaka City Hospital

大量下血をきたしたと思われる盲腸脂肪腫を 1 例経験したので，若干の文献的考察を 加えて報告する。

症例は下血を主訴として入院し，入院 2 日目に大量下血を認めた．注腸造影及び大腸 内視鏡検查で回盲部の粘膜下腫瘤から一過性に出血したものと考文，回盲部切除術を施 行した. 切除標本では, 盲腸に $4.3 \times 1.8 \mathrm{~cm}$ 大の隆起性腫瘤が認められ, 組織学的には粘 膜下に成熟した脂肪細胞からなる腫瘍であった。

盲腸脂肪腫の本邦23手術症例のらち，大量下血をきたした症例はなく自験例が最初で ある。手術後 2 年余りが経過するも，再下血は認められず便潜血は陰性である。

柬引用語 : 大量下血, 盲腸脂肪腫

はじめに

従来消化管の脂肪腫は比較的まれな疾患とされ，中 でる本邦における盲腸脂肪畽の報告は少ない，最近わ れわれは大量下血をきたしたと思われる盲腸脂肪腫を 1 例経験したので，本邦23手術症例の検討及び文献的 考察を加えて報告する。

\section{I. 症 例}

患者：46歳, 男性.

主訴：下血。

既往歴：36歳時, 胃潰煌にて胃切除術 (Billroth I) を受けた。

家族歴：特記すべきことなし。

現病歴：1980年12月 6 日に, 突然に下血, 冷汗, 倦 急感が出現した。翌朝, 再び下血があり当科に婜急入
院した。

現症：体格・栄養ともに中等度. 眼䀫結膜に負血あ

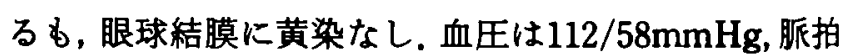
66/分整. 全身の表在リン八節は触知せず. 胸部理学的 所見に異常はなかった，腹部は平坦軟で，肝・脾・腎 や他に腫瘤は触知しなかったが，右下腹部に圧痛を認 めた。

入院検査成繶: 検血は赤血球数 $308 \times 10^{4} / \mathrm{mm}^{3}$, へマ トクリット值 $30 \%$ ， 一モグロビン值 $10.3 \mathrm{~g} / \mathrm{dl}$ で費血を 認め, 便潜血反応は強陽性であった。 CEA, AFPは正 常であった。血清電解質, 肝機能, 心電図, 胸部レ線 像に異常を認めなかった（表 1 ）。

入院後 2 日目に大量の下血を認め, 赤血球数 $210 x$ $104 / \mathrm{mm}^{3}$, ヘマトクリット值 $19 \%$, へモグロビン值 6.4 


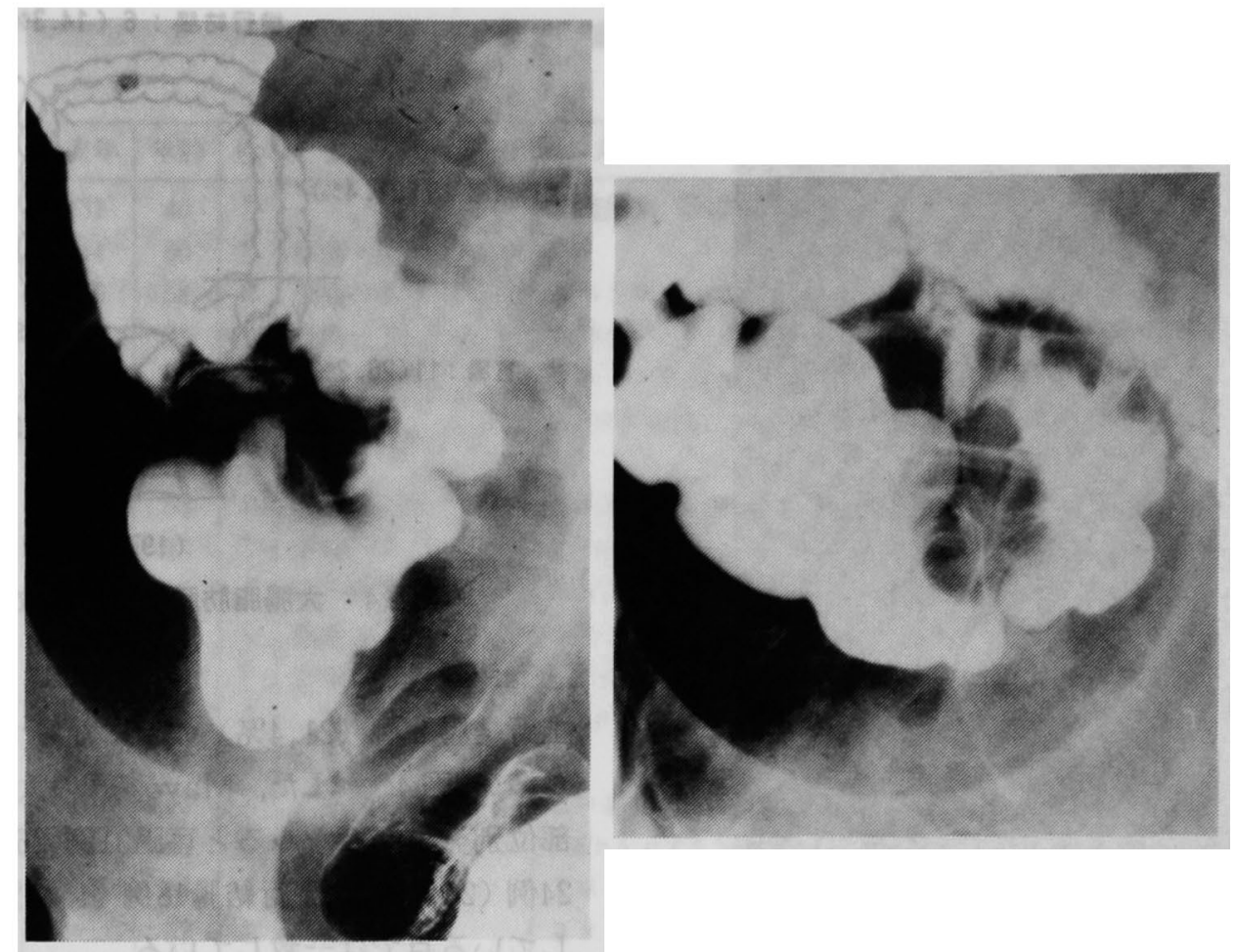

図 1 注驔造影：Bauhin 升付近に辺縁平滑な隆起性病変が認められる。

表 1 入院時検查成绩

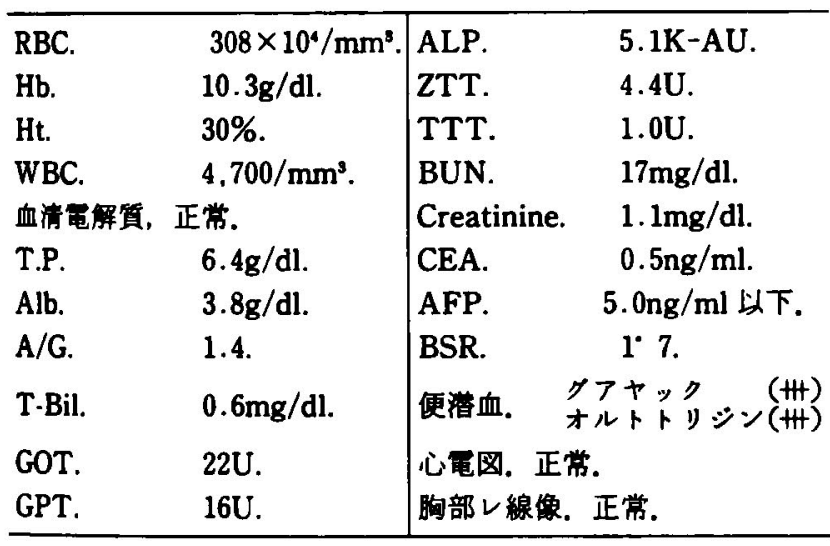

g/dl, 血圧 $92 / 50 \mathrm{mmHg}$ まで低下した。

上部消化管造影所見：胃・小腸透視では異常を認め なかった。

注渴造影所見：Bauhin 弁付近に大きさ $4 \times 2 \mathrm{~cm}$, 辺 绿が平滑な隆起性病变が認められ，回盲部尰瘤が筑わ れた（图 1 ).

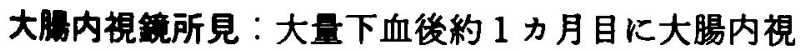
鏡検查を行った，正常粘膜に覆われた隆起性腫瘤が回 自部に認められたか，この時には，表面に潰演形成， 出血などは認められなかった，その時におこなった腯 瞥の生検所見はGroup 1であった。他の部位に出血性 病変は見られなかった。

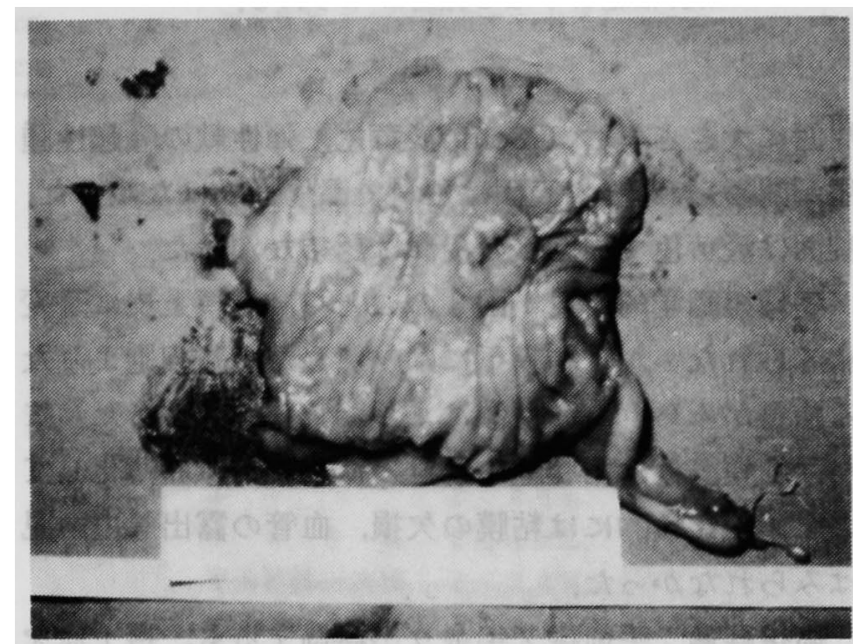

図 2 标出标本：Bauhin 弁周囲に隆起性腫瘤が認め られる。

以上の諸検查の結果から,われわれは回盲部の粘膜 下腫瘤より一過性に出血したすのと考古1982年 2 月 5 日手術を施行した。

手術所見：腹水，肝転移，腹膜播腫の所見はなかっ た. 回盲部の浆膜面には変化がなかったが, 内胵に鵎 卵大の軟かい腫瘤を触知した。回結腸動脈，上腸間膜 動脈領域にはリンパ節の腫大を認めなかった。畽瘤を 中心に約 $12 \mathrm{~cm}$ の回盲部切除を施行した.

切除标本肉眼所見：図 2 で示すよ5に, Bauhin 弁 


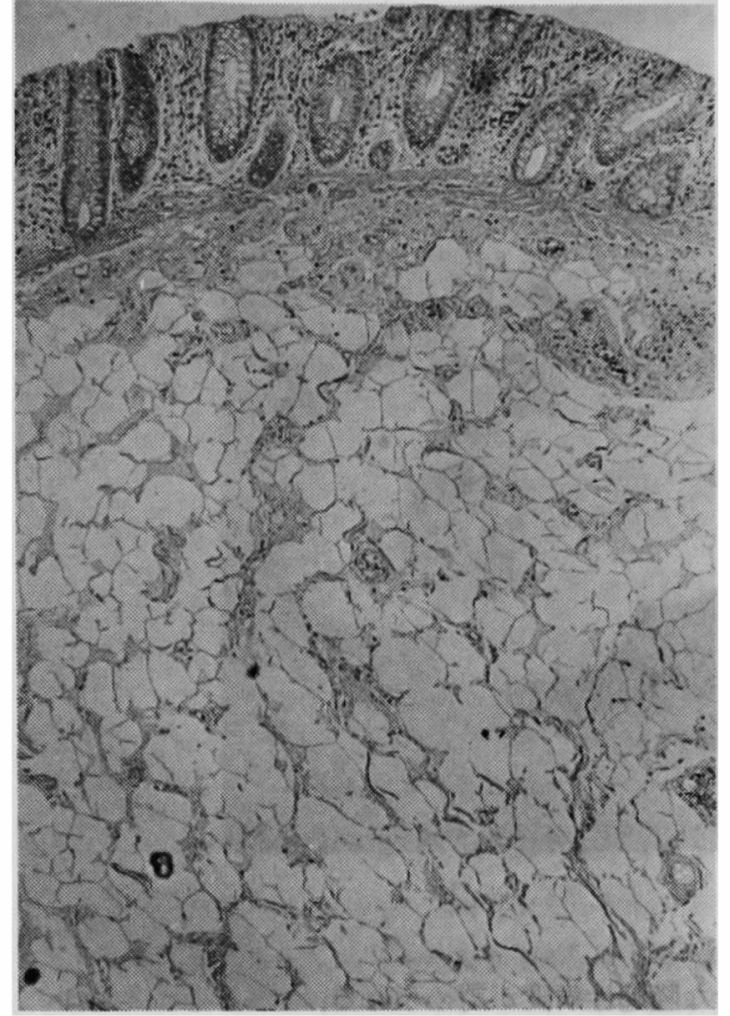

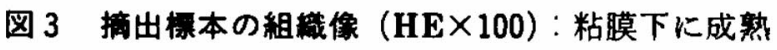
した脂肪細胞よりなる腫痬がみられる。

周囲に大きさ $4.3 \times 1.8 \mathrm{~cm}$, 淡黄色, 弾性軟の隆起性腫 瘤が認められ,その表面は平滑で漬痬形成はなかった。 割面は淡黄色で周囲への漫潤は認めなかった。

病理組織学的所見：図 3 のごとく，粘膜上皮に著变 はみられないが，粘膜下には成熟した脂肪細胞よりな る腫場がみられ，異型像はまったく認めなかった。 た, 粘膜筋板は脂肪腫の王排のため非常に菲薄化して いた，組織学的には粘膜の欠損，血管の露出等の所見 はみられなかった。

術後経過：手術後 2 年余りが経過するる, 再下血を 認めず，便潜血は陰性である。

\section{II. 考 按}

大腸脂肪畽の剖検例での発生頻度は, 原ら゙が $3.1 \%$, 石原ら ${ }^{2)} 2.9 \%$ と報告しており，脂肪腫は決し て稀な腫瘍ではないが，大きく発育し症状が出現する ものは少ないために，臨床的には稀とされている.

遠藤ら ${ }^{3)}$ によると消化管脂肪腫のうち大腸に発生す るものは $19.3 \% て ゙ ，$ 胃に発生するむの $40.8 \%$ ，小腸に 発生するもの34.6\%についで第 3 位であると報告され ている. 1979年の第11回大腸癌研究会の集計4)には, 大 腸脂肪腫として42例が報告されている．その発生部位 の頻度は盲腸11例 (26.2\%)，S 状結腸10例 (23.8\%)，

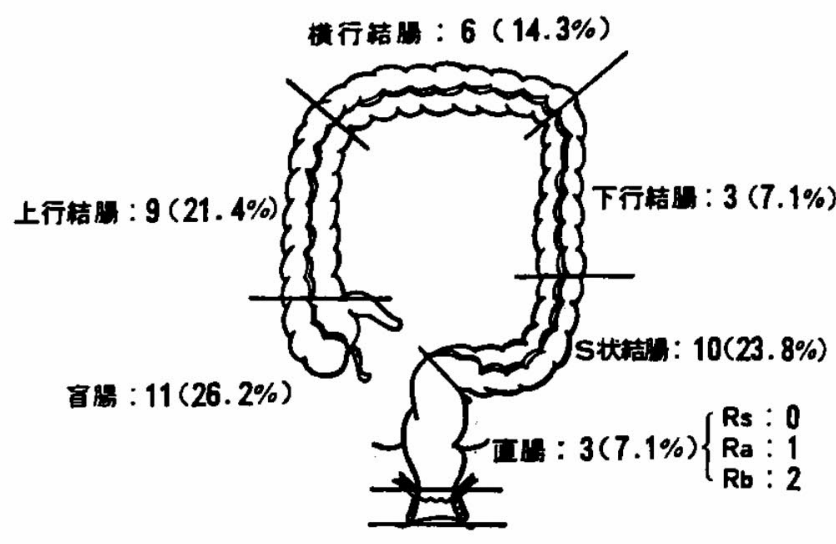

（1979年禹11 回大学害研究会）

园 4 大腸脂肪还の占居部位（42例）

上行結腸 9 例 $(21.4 \%)$ の順になっており盲腸に発生 が多い(図 4 )。京た，Mayo ら5)の大腸脂肪畽119例の 部位別発生頻度をみると盲腸 31 例(26.1\%), 横行結腸 24 例 (20.2\%), 下行結腸18例 (15.1\%) で盲腸に好発 している点では一致している。

われわれの調べ得た範囲では，盲腸に発生した脂肪 腫は1931年足立 ${ }^{6)}$ によ本邦第 1 例の報告がなされて 以来，自験例を含め23例が報告されている（表 2 ）.

その発生年齢は39歳から75歳にわたり，平均年龄は 54.5歳である. 40 歳から60歳台に発症年齢のピークが あり，全23例中の20例（86\%）はこの年齢齢層に属し ている。

性別では，男性13例，女性 9 例で男性にやや好発し ている.

腫愓の大きさは明らかなるのについて $5 \mathrm{~cm}$ 以上が 6 例 (40\%), $5 \mathrm{~cm}$ から $2 \mathrm{~cm}$ が 9 例 (53\%), $2 \mathrm{~cm}$ 以下 が 1 例であった。

盲腸脂肪腫の症状は腹痛が最も多く23例中14例 (63.6\%) にみられ，次に下血 4 例 (18\%) が認められ た。本症の下血については, 脂肪腫の循摆障害および 腸内容による機械的刺激のために形成された被覆粘膜 のびらんや潰痬からの出血によると考兄られている. $D^{\prime} J^{2}$ avid $^{7}$ は，下血の頻度は腫瘤が肛側に発生するにつ れて多くなり，この原因は腸内容が有形・固形化して 固くなり，粘膜表面をこするためであると述べている， 彼の大腸脂肪腫278例の集計によると,何らかの下血が 認められた症例数は138例 (49.6\%)であったか，大量 下血をきたしたのは 3 例のみであったといら．本邦盲 腸脂肪腫報告例で大量下血をきたした症例はなく自駼 例が最初である。なお，自験例では出血以来 2 力月後 の摘出標本の表面にはすでにびらん・潰劰を認めず, 


\section{表 2 盲腸脂肪胵}

\begin{tabular}{|c|c|c|c|c|c|c|c|c|c|}
\hline & & & & & & & & 一直本邦却告偧 & {[} \\
\hline No & 報告者 & 発表年 & 年龄 & 性 & 臨床症状 & 大き & 形 状 & 療 & 腸重筫 \\
\hline 1 & 足 立() & 1931 & 40 & $\hat{\delta}$ & & (1)䋦卵大 (2)拇指頭大 & & & - \\
\hline 2 & 工 藤(15) & 1944 & 60 & $\delta$ & 疼痛・発熟 & & 多房性 & 回盲部切除 & - \\
\hline 3 & 平 松10) & 1969 & 58 & $\hat{\delta}$ & 腹痛 & $6 \times 5 \times 4 \mathrm{~cm}$ & & 手 術 & + \\
\hline 4 & 高 橋(17) & 1974 & 39 & $\hat{\delta}$ & 腹痛 & 鵎卵大 & & 右半結腸切除 & + \\
\hline 5 & 有 本 ${ }^{\prime \prime \prime}$ & 1975 & 49 & 우 & 腹痛・血便 & $4 \times 4 \times 2.5 \mathrm{~cm}$ & 有茎性 & 回盲部切除 & + \\
\hline 6 & 薏 藤 ${ }^{3)}$ & $"$ & 58 & $\hat{\delta}$ & 疝痛 & $5.0 \times 6.0 \mathrm{~cm}$ & 有茎性 & 右半結腸切除 & + \\
\hline 7 & 山 $口^{18)}$ & 1976 & & & & & & & \\
\hline 8 & 津 奏19) & " & 54 & 우 & 腹痛 - 便秘 & $5 \times 3.5 \times 3.5 \mathrm{~cm}$ & 垔有茎性 & 右半結晹切除 & + \\
\hline 9 & 若 林 ${ }^{201}$ & " & 43 & $\hat{\delta}$ & 下琍 & $3.0 \times 2.9 \mathrm{~cm}$ & & 回盲部切除 & \\
\hline 10 & 中 $\|^{211}$ & 1977 & 65 & $\delta$ & 楉尿病精査 & $3 \times 3.5 \mathrm{~cm}$ & 有茎性 & 回盲部切除 & - \\
\hline 11 & 守 田 ${ }^{22)}$ & $"$ & 56 & + & 腹痛 & $6 \times 5 \mathrm{~cm}$ & & 回目部切除 & + \\
\hline 12 & 杉 原 ${ }^{23)}$ & $" 1$ & 44 & 우 & 右季肋部痛 - 血便 & $4.5 \times 4.0 \times 3.0 \mathrm{~cm}$ & & 右半結腸切除 & - \\
\hline 13 & 简 井 ${ }^{14)}$ & 1978 & 66 & 우 & & $1.4 \times 1.0 \mathrm{~cm}$ & 広基性 & 腫瘤剔除 & - \\
\hline 14 & 涉 谷 ${ }^{241}$ & $"$ & 63 & f & 右側腹部痛 & & & 右半結腸切除 & + \\
\hline 15 & 有 本 $^{111}$ & 1979 & 40 & 우 & 右下腹部痛 & $5 \times 4.2 \times 3.3 \mathrm{~cm}$ & 有茥性 & 回盲部妡除 & - \\
\hline 16 & 山 川 & " & 45 & $\hat{\delta}$ & 腹痛 - 呕吐 & $4.5 \times 4.0 \times 3.5 \mathrm{~cm}$ & 有荲性 & 右半結腸切除 & + \\
\hline 17 & 固 武26) & 1980 & 68 & + & 下䐓部疝痛 & $4 \times 5 \mathrm{~cm}$ & & & + \\
\hline 18 & $"$ & $"$ & 63 & $\hat{\delta}$ & 便秘 & $2 \times 2 \times 1 \mathrm{~cm}$ & 垔有茎性 & 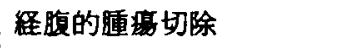 & - \\
\hline 19 & 近 添 ${ }^{271}$ & " & 51 & $\hat{\delta}$ & 右下腹部痛 & $5 \times 4.5 \times 4.5 \mathrm{~cm}$ & 分葉状 & 回盲部切除 & - \\
\hline 20 & 中 里 ${ }^{28)}$ & " & 62 & $\hat{0}$ & 右季助部痛 & $5 \times 4 \times 2.5 \mathrm{~cm}$ & 有茥性 & 回盲部切除 & - \\
\hline 21 & 西 城29) & 1981 & 75 & + & 血便 & & 有茥泩 & 内視鏡的ボリベクト & - \\
\hline 22 & 太 $\mathbb{⿴ 囗 十}^{301}$ & 1982 & 56 & $\delta$ & 右下腹部痛 & $2.5 \times 1.5 \mathrm{~cm}$ & 垔有茎性 & 内視鏡的ボリヘクトミー & - \\
\hline 23 & 自験例 & 1982 & 46 & $\delta$ & 下血 & $4.3 \times 1.8 \mathrm{~cm}$ & 広基性 & 回盲部奵除 & - \\
\hline
\end{tabular}

下血の原因は敛密には不明であるが術後今日迄 2 年以 上観察するも再下血を認めていない点から大量下血は 脂肪腫によるものと推察される。

また，盲腸脂肪腫23例のうちの 9 例 $(45 \%)$ に腫重 積症が認められた。饗場ら日ににると1950年から1975 年までの25年間における本邦成人腸重積症202例中結 腸腸重積症は17例で，その内 9 例は悪性腫焬によるむ のであるが，残り8例の良性畽惕によるるのの内で実 に6 例までが脂肪腫によるものであると報告されてい る。

脂肪腫自体の悪性化はないといわれているが，消化 管脂肪尰と消化器癌との合併についてみると Mayo ら5)は164例の消化管脂肪腫中胃癌の合併 1 例, 結腸癌 の合併47例を報告しており，内 3 例は脂肪腫に接して， また 4 例は脂肪腫より $5 \mathrm{~cm}$ 以内に癌を認めたという。 本邦では上行結腸脂肪腫の頂上粘膜面に腺癌がみられ た例”，直腸癌を合併した S 状結腸脂肪腫の報告 ${ }^{10)} か$ あるが盲腸脂肪腫の集計には認められていない。

大腸脂肪腫の術前診断は, 第11回大腸癌研究会集 計) によると粘膜下腫瘍 $38.1 \%$, 癌 $16.7 \%$, 腸重積症 $11.9 \%$ ，属湯 $11.9 \%$ となっており，術前に大腸脂肪畽

\section{表 3 大得脂肪腯の術前診断 (42例)}

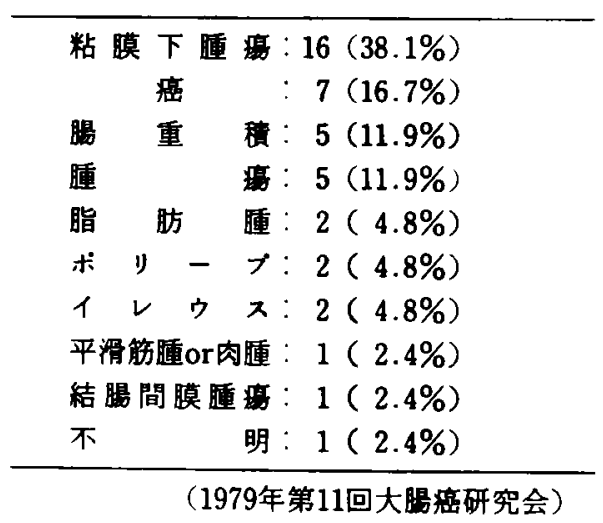

と診断されたものは4.8\%にすぎない（表 3）.

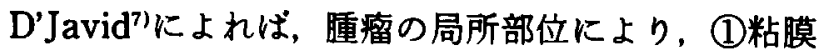
下，(2)将下，(3)粘膜浆膜内の 3 つのタイブに分けて いるが，有本ら ${ }^{11}$ によると本邦大腸脂肪腫の約 $60 \% か ゙$ 粘膜下タイプであると報告している，粘膜下タイプの 大腸脂肪畽の内視鏡所見としては，表面が平滑で淡黄 色を帯び，触れると軟らかいことが特致とされている が，粘膜下腫場といら性格から生検を併用しても確診 を下すことは困難と考えられる。 
同じ粘膜下腫湯を呈する細網肉腫, リンバ肉腫, カ ルチノイドなどす念頭において鑑別しなければならな い.

大腸脂肪腫の注腸 X線像の特徽としては，X線透過 性が大である球形または卵円形の腫瘤像で，压迫によ り時に変形をきたすことがあるといわれている。盲腸 脂肪腫が疑われたら，水と脂肪組織のコントラストか

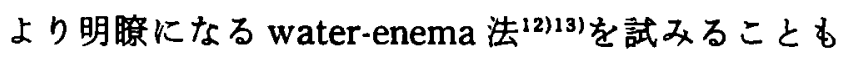
有用と報告されている。

盲腸脂肪腫23例の治療は記載の明らかなものについ て回盲部切除 9 例 (47\%), 右半結腸切除 6 例 (31\%), 腫瘍摘出 2 例 (10\%), 内視鏡的ポリベクトミー2 例 (10\%)であった。本疾患は良性腫湯であり，畽湯のみ の摘出が理想的で, 侵襲の大きい右半結腸切除は可能 な限り避けるべきであるが，術前大腸脂肪腫の正診率 $4.8 \%$ () と示す様に実際には診断困難な場合が多い，筒 井ら゙は，脂肪畽が疑われたら，開腹所見に加えて腸切 開術により内腔を精査し, 必要あれば腫瘤の迅速切片 検查によって良性·悪性の判定をくだすことが重要で, 腫瘍が大きいむのでは腸切除もやむをえないが，小さ いものでは剔出のみで充分であると主張している。 た，前述の如く近くに癌を合併している場合があるこ とを念頭に拈いて周囲を十分に検索して手術方針を決 定すべきであろう.

\section{IV. 結 語}

大量下血をきたしたと思われる盲腸脂肪腫の症例を 経験した．盲腸脂肪腫は比較的稀なものであり，本邦 では文献上23例の集計がみられ若干の考察を加えて報 告した。

\section{文 献}

1）原 宏介, 相沢暁太郎, 山域 守他：大腸の非上皮 性良性腫瘍一1,130例の連続剖検例による一, 大腸 肛門誌, $30: 498-504,1977$.

2）石原明困，山際裕史，松崎 : 大晹脂肪腫一手 㭪および剖検例の臨床病理学的検討一, 癌の臨床, $26: 376-381,1980$.

3）遠藤正三郎，佐藤方紀，磯本 徹地：消化管脂肪腫 一結腸脂肪腫を中心として一, 臨床外科, 30 ： 261-268, 1975.

4）第11回大腸癌研究会：大腸非上皮性瘇瘍フンヶー 卜調查, 1979.

5) Mayo, C.W., Pagtaluman, R.J.G. and Brown, D. J. : Lipoma of the alimentary tract. Surgery, $53: 598-603,1963$.
6）足立信道：腸管脂肪睡の 1 例， 日外宝， $8: 104$, 1931.

7) D'Javid, I.F.: Lipoma of the large intestine: Review of the literatures and report of a case. The Journal of the International College of Surgeons, $33: 639-668,1960$.

8）㗽場庄一, 塩崎秀郎, 遠藤敬一他：小腸脂肪腫の 4 治検例と本邦に批りる成人腸重積症ならびに腸管 脂肪隀の珫計的考察，日臨外会誌，38：65-71, 1977.

9）石井堯典：癌腫を併発した上行結晹脂肪尰の 1 例，外科，11:247，1949.

10）金政誠：腸重積をおこした横行結腸脂肪重に直 腸癌を合併した 1 治験例，第31回日本大腸肛門学 会総会, 1976.

11）有本重也, 内藤行雄，上山鬼弘他：結腸脂肪睡一自 検 3 例と本邦報告例の検討一, 日臨外会誌，39： 84-92, 1978.

12) Margulis, A.R.: The roentgen diagnosis of submucous lipomas of the colon. Amer. J. Roentgenology, $84: 1114,1960$.

13）鉿木 昇，渡辺 茪，後藤由夫：大腸脂肪畽の 3 例 一とくに water enema 法について一，胃と腸， $14: 1249-1254,1979$.

14）筒井 完, 上村恭一, 上西 七他：盲腸脂肪腫の 1 例, 日臨外会誌, $39: 540-544,1978$.

15）工藤達之：虫垂炎性朖瘍之誤った盲腸外脂肪腫の 1 例, 診断と治療, $32 ： 98-99,1944$.

16）平松 収：腸重棈を呈した盲腸腫福の 3 例，日医 放会誌，29：113，1969.

17）高橋任夫：盲腸脂肪腫による回盲部腸重積症の 1 治呀例，医療，28：2315，1974.

18）山口一紘, 一瀬 裕, 長兵 特異な形態を呈 した忘晹脂肪尰の 1 例，日消誌，73：740，1976。

19）津泰健治，松本孝一，庄司宗弘他：結腸重稳症を来 たした脂肪畽の 2 例，日臨外会誌，37：663，1976.

20）若林芳敏，小笠原隆，佐々木㷮男他：大渴脂肪尰の 2 症例，大腸肍門誌，30：232，1977.

21）中川研一, 細馬静昭, 中谷一霞他：結腸脂肪連の一 例，広島県立病院年報， $9: 189 ， 1977$.

22）守田知明，小田说郎，森田耕一郎他：比䖝的稀大消 化管畽瘍による成人腸重糟症の 2 例, 日臨外会誌, $38: 499-502,1977$.

23）杉原発司，古賀成昌：盲腸脂肪尰の 1 例，島根医 学, $5: 864-868,1977$.

24）沾谷知顕，須原邦和，三尾六藏他：腸閉塞を呈した 
盲腸粘膜下脂肪腫の 1 例，日外会誌，79：158, 1978.

25）山川知洋：腸重櫴症を起こした盲腸脂肪腫の1 例、日臨外会誌, $15 ： 639 ， 1979$.

26）固武健二郎, 小平 進, 露木 晃他：大腸非上皮腫 場の経験例，大腸肛門誌，33：150，1980。

27）近添拓世, 佐藤蒸隆, 伊藤正秀他：結腸脂肪㞒の 3 治検例，大腸肛門誌，33：150-151，1980。

28）中里博子, 虂川桂三, 市村経敏他：盲腸に存在した
巨大脂肪腫の一例, 臨床と研究, $57: 3972-3974$, 1980.

29）西城前郎，中島峻雄, 坪井正夫他：内視鏡的に切除 した大腸脂肪腫の 1 例，日消誌，78：771-774, 1981.

30）太田博鄉，䄸引 元，中野 哲他：内視鏡的ボリペ クトミーにより摘除しえた大腸脂肪睡の 2 例, Gastroenterological Endoscopy, 24:1446 $-1451,1982$. 